\title{
Water uptake and pre-germination treatments in macaw palm (Acrocomia aculeata - Arecaceae) seeds ${ }^{1}$
}

\author{
Ailton Gonçalves Rodrigues Junior²*, Túlio Gabriel Soares Oliveira ${ }^{2}$, \\ Patrícia Pereira de Souza ${ }^{3}$, Leonardo Monteiro Ribeiro ${ }^{4}$
}

\begin{abstract}
The aims of this study were to evaluate the influence of embryo adjacent tissues in water uptake and treatments to release dormancy in macaw palm seeds. To assess water absorption with or without the opercular tegument (OT), seeds were immersed in water for $0,12,24,48,72,96,120,168,240,360,480$ and 720 hours and the water content of isolated embryos and seeds was determined. In seeds with or without OT, gibberellic acid $\left(\mathrm{GA}_{3}\right)$ solutions at concentrations of 0, 50, 100, 500, 1000 and $2000 \mathrm{mg} . \mathrm{L}^{-1}$ were applied on the OT region using a culture medium. In another experiment, the OT was removed or left intact and the seeds immersed in hydrogen cyanamide solutions $(0,0.5,1,1.5,2$ and $2.5 \%)$. The percentage germination, germination speed index (GSI) and percentage dead seeds were determined. The OT does not prevent embryo water uptake but reduces water absorption speed. The use of $\mathrm{GA}_{3}$ in a culture medium applied to the OT region did not effectively release dormancy. The use of cyanamide at these concentrations increased seed mortality, resulting in a low germination. OT removal increased the GSI.
\end{abstract}

Index terms: imbibition, opercular tegument, $\mathrm{GA}_{3}$, hydrogen cyanamide.

\section{Absorção de água e tratamentos pré-germinativos em sementes de macaúba (Acrocomia aculeata - Arecaceae)}

\begin{abstract}
RESUMO - O objetivo neste trabalho foi avaliar a influência de tecidos adjacentes ao embrião na absorção de água pela semente e de tratamentos de superação de dormência em macaúba. Para avaliar a absorção de água, sementes com ou sem a remoção do tegumento opercular (TO) foram imersas em água durante 0, 12, 24, 48, 72, 96, 120, 168, 240, 360, 480 e 720 horas e determinado o teor de água de embriões isolados e sementes. Em sementes submetidas ou não à remoção do TO, aplicou-se ácido giberélico $\left(\mathrm{GA}_{3}\right)\left(0,50,100,500,1000\right.$ e $\left.2000 \mathrm{mg} . \mathrm{L}^{-1}\right)$ sobre a região do TO, tendo meio de cultura como veículo de aplicação. Em outro experimento, sementes com ou sem TO foram imersas em soluções de cianamida $(0 ; 0,5 ; 1 ; 1,5$; 2 e 2,5\%). Foi avaliado o percentual de germinação, índice de velocidade de germinação (IVG) e porcentagem de sementes mortas. O TO não impede a absorção de água pelo embrião, mas diminui a velocidade de embebição. O uso de GA 3 sobre a região do TO não favorece a germinação e a cianamida hidrogenada nas doses utilizadas aumenta a mortalidade das sementes, proporcionando baixa germinação. A remoção do TO possibilita acréscimo no IVG.
\end{abstract}

Termos para indexação: embebição, tegumento opercular, $\mathrm{GA}_{3}$, cianamida hidrogenada.

\section{Introduction}

The macaw palm, Acrocomia aculeata (Jacq.) Lodd. ex. Mart. (Arecaceae), is a tropical palm widely distributed throughout Brazil (Lorenzi et al., 2004) and its occurrence in Minas Gerais state is associated with eutrophic soils (Motta et al., 2002). This species is a very productive oil-producing plant and has a high potential for producing biofuels, especially in

${ }^{1}$ Submitted on 05/24/2012. Accepted for publication on 09/26/2012. ${ }^{2}$ Departamento de Ciências Florestais, Universidade Federal de Lavras, Caixa Postal 3037, 37200-000 - Lavras, MG, Brasil.

${ }^{3}$ Departamento de Fitotecnia, Universidade Federal de Viçosa, 36570-000 Viçosa, MG, Brasil. dry tropical regions (Moura et al., 2010; Dias, 2011).

The germination of macaw palm seeds is low due to dormancy (Lorenzi et al., 2004; Ribeiro et al., 2011) and, therefore, breaking dormancy is important for producing seedlings on a commercial scale (Lorenzi et al., 2004).

Water absorption is the first stage in germination and can occur in different ways in seed tissues (McDonald Jr. et al., 1988). According to Bewley and Black (1994), the

${ }^{4}$ Departamento de Biologia Geral, Unimontes, Caixa Postal 126, 39401-089 Montes Claros, MG, Brasil.

*Corresponding author < ailtongrodrigues@gmail.com> 
embryo absorbs water continuously at a greater speed due to cell elongation and division, in contrast to other seed tissues where there is no tissue expansion. Seed imbibition by water immersion can harm embryos due to the rapid absorption and lower diffusion of oxygen (Marcos-Filho, 2005).

Dormancy has been characterized as blocking the conclusion of germination (Bewley, 1997) and can be classified as physiological, morphological, morphophysiological, physical and a combination between physical and physiological dormancy (Baskin and Baskin, 2004; FinnchSavage and Leubner-Metzger, 2006). Cases of morphological dormancy are common in palm seeds (Orozco-Segovia et al., 2003), but studies with isolated embryos of macaw palm demonstrate that dormancy due to embryo immaturity does not occur in this species (Ribeiro et al., 2012), and it can be classified as nondeep physiological dormancy (Baskin and Baskin, 2004; Finnch-Savage and Leubner-Metzger, 2006).

Various pre-germination treatments are used to overcome dormancy in palm seeds, such as heat treatments (Hussey, 1958; Rees, 1961; 1962; Addae-Kagyah et al., 1988; Meerow, 1991; Robinson, 2009), pre-immersion in water (Meerow, 1991), removal of the operculum (Hussey, 1958; Carpenter et al., 1993; Al-Wasel and Warrag, 1998; Pérez et al., 2008) and of the endocarp (Merrow, 1991; Pérez et al., 2008), and chemical treatments (Nagao et al., 1980; Pérez et al., 2008; Roberto and Habermann, 2010).

The positive effect of gibberellic acid $\left(\mathrm{GA}_{3}\right)$ and the removal of the opercular tegument were observed in the germination of macaw palm seeds (Ribeiro et al. 2011), and also in the Pritchardia remota palm (Pérez et al., 2008). The use of this plant growth regulator has also proved efficient in breaking seed dormancy in other palm species, such as Euterpe edulis (Roberto and Habermann, 2010), Archontophoenix alexandrae and Ptychosperma macarthurii (Nagao et al., 1980). However, the high cost of $\mathrm{GA}_{3}$ and the difficulty in diffusion of solutions through the seed tissues (Nagao et al. 1980, Ribeiro et al., 2011) has encouraged studies on new ways of applying this growth regulator.

Hydrogen cyanamide $\left(\mathrm{CH}_{2} \mathrm{~N}_{2}\right)$ is an organic compound used to induce bud sprouting and release seed dormancy (Shulman et al., 1983; Herrera et al., 1998; Jiménez et al., 2008). The efficiency of this compound in release seed dormancy was demonstrated for the Elaeis guineensis palm, where it stimulated germination (Herrera et al., 1998; Jiménez et al., 2008).

The aim of this study was to evaluate the influence of seed structures on water absorption by the embryo, the effect of $\mathrm{GA}_{3}$ dosages applied by culture medium and of hydrogen cyanamide dosages, in breaking dormancy in macaw palm seeds.

\section{Material and Methods}

Collection and preliminary procedures: fruits were collected after abscission from 20 individuals of $A$. aculeata from natural populations in Montes Claros county (16 42 '34'S; $\left.43^{\circ} 52^{\prime} 48^{\prime \prime} \mathrm{W}\right)$, in the north of Minas Gerais state. The fruits were stored in the shade until the experiments were carried out and, remained in this condition for a maximum of eight months.

Seeds were removed from the fruits before each experiment, with the aid of a benchtop vice, were selected and damaged seeds were discarded. Seed water content was determined using the oven method with five replications of ten seeds (Brasil, 2009). The seeds were disinfected in $6 \%$ chlorine solution for 10 minutes, followed by three washes in running water. The opercular tegument was removed with a razor blade, using a stereomicroscope to avoid embryo damage (Ribeiro et al., 2011).

Water absorption: the fruits for this experiment were collected in 2008, with the seed being extracted from the fruits and the opercular tegument removed from half of them. Seeds, with and without the opercular tegument, were immersed separately in water in $2 \mathrm{~L}$ beakers, changing the water daily. Imbibition occurred at ambient temperature. Before immersion and after 12, 24, 48, 72, 96, 120, 168, 240, 360,480 and 720 hours of imbibition, five replications of 10 seeds from each treatment were removed and the embryo was isolated using scalpels in order to determine the water content of the embryo and the rest of the seed (endosperm + tegument), using the oven method (Brasil, 2009). The experimental design was completely random.

Application of $\mathrm{GA}_{3}$ by culture medium: the seeds used in this experiment were collected in 2009, extracted from the fruit and kept in polystyrene trays containing vermiculite. Seeds were submitted to pre-imbibition in vapor in a humid growth chamber with $95 \pm 5 \%$ of $\mathrm{RH}$ at $30{ }^{\circ} \mathrm{C}$ for one week. After the pre-imbibition, the seeds were disinfected with $2 \%$ chlorine solution for 10 minutes.

The opercular tegument was removed from half the seeds and $1 \mathrm{~mL}$ of culture medium was applied on the micropylar region with a $10 \mathrm{~mL}$ hypodermic syringe. The MS medium was used (Murashige and Skoog, 1962), supplemented with 10 g. $\mathrm{L}^{-1}$ of agar and autoclaved at $121{ }^{\circ} \mathrm{C}$ for 20 minutes, with different dosages of $\mathrm{GA}_{3}$ added $(0,50,100,500,1000$ and $\left.2000 \mathrm{mg} . \mathrm{L}^{-1}\right)$, filtered in a Millipore ${ }^{\circledR}$ membrane with $0.45 \mu \mathrm{m}$ mesh and added after the medium had reached $50{ }^{\circ} \mathrm{C}$.

After application of the culture medium, the seeds were returned to the humid growth chamber. The vermiculite was moistened daily with a squeeze bottle. The experimental 
design was randomized blocks in a $6 \times 2$ factorial $\left(\mathrm{GA}_{3}\right.$ concentrations $x$ seeds with or without the opercular tegument), with five replications of 20 seeds per treatment. The seeds were evaluated weekly for four months and the germinated seeds (considering germination as the protrusion of the cotyledonary petiole) and dead seeds were removed after counting. The percentage germination, germination speed index (GSI) (Maguire, 1962) and percentage dead seeds was calculated.

Immersion in hydrogen cyanamide solution: another seed lot collected in 2009 was used for this experiment. Seeds were extracted from the fruits, disinfected and submitted to pre-imbibition as described in the previous experiment. The opercular tegument was removed from half the seeds and these were immersed in hydrogen cyanamide solutions (Dormex ${ }^{\circledR}$ ), for 24 hours with different concentrations of the commercial formulation $(0,0.5,1,1.5,2$ and $2.5 \%)$ and returned to the humid growth chamber. After six weeks, the seeds were removed from the vermiculite and the hydrogen cyanamide treatment was repeated.

The experimental design were randomized blocks in a 6 x 2 factorial (cyanamide dosages x seeds with or without the opercular tegument), with five replications of 20 seeds per treatment. The seeds were evaluated weekly during 13 weeks using the same criteria described for the previous experiment. Those seed embryos which remained hard until the end of the experiment were submitted to the tetrazolium test, using four replications of 10 embryos, which were immersed in a $0.5 \%$ solution of 2,3,5-triphenyl tetrazolium chloride at $35^{\circ} \mathrm{C}$ for four hours, according to the methodology described by Ribeiro et al. (2010). The tetrazolium test was used in this experiment to evaluate the toxicity of the hydrogen cyanamide on the embryos.

Statistical analysis: an analysis of variance was done with the data on percentage germination and dead seeds transformed to arc sine $\sqrt{x} / 100$, and the means were compared using Tukey's test at 5\% probability (SAS Institute, 1990). Water absorption and embryo viability data were submitted to a regression analysis and the model adjustment was tested at the $5 \%$ significance level and evaluated with the determination coefficient $\left(\mathrm{R}^{2}\right)$ using the SigmaPlot v.11.0 software.

\section{Results and Discussion}

Water absorption: before imbibition, the isolated embryos and the rest of the seeds (endosperm + tegument) had water contents of 7.3 and $6.5 \%$ respectively. During imbibition, the highest absorption rate occurred in seeds without the opercular tegument up to approximately 240 hours of imbibition (Figure 1). After this period, the embryos from seeds with and without the opercular tegument contained water contents close to, and higher than the rest of the seeds, reaching percentages higher than $49 \%$ after 720 hours of imbibition. The endosperms + teguments, in both conditions, showed similar imbibition behavior, with a slow and gradual increase in water content until a plateau was reached after 360 hours imbibition, with 20.9 and $22 \%$ of water content in seeds with and without opercular tegument, respectively, after 720 hours imbibition.

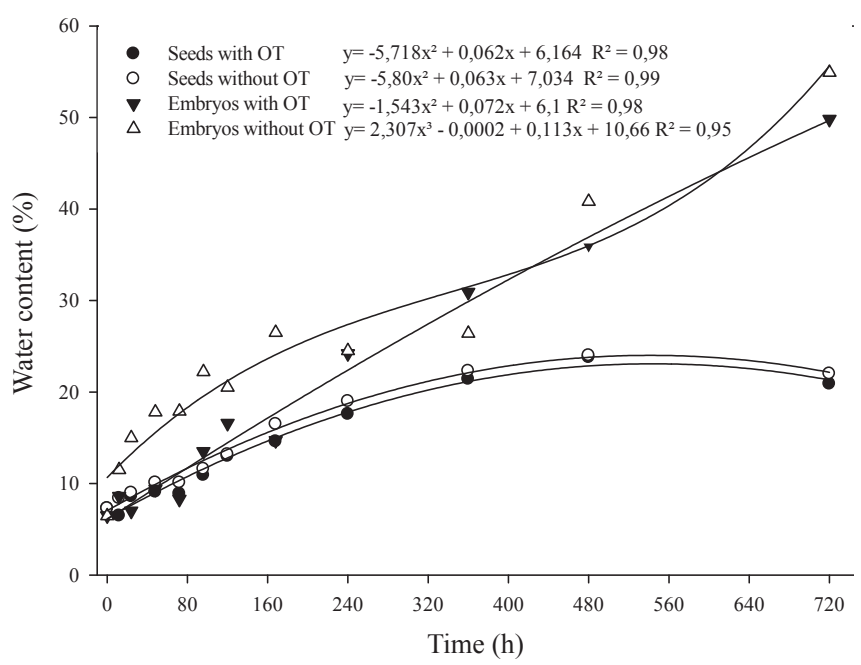

Figure 1. Water contents of seeds (endosperm + tegument) and embryos of $A$. aculeata, with or without the opercular tegument (OT), after different periods of water immersion.

Application of $\mathrm{GA}_{3}$ by culture medium: the seeds had water content of $22.4 \%$ before the experiment. The removal of the opercular tegument had a positive effect on germination and the GSI (Table 1), but without effect of the $\mathrm{GA}_{3}$. The removal of the opercular tegument and the $\mathrm{GA}_{3}$ affected the mortality percentage of seeds, with an interaction between these variables (Figure 2). In seeds which had the intact opercular tegument this percentage was unaffected by the use of $\mathrm{GA}_{3}$, whereas in seeds without the opercular tegument there was higher mortality without or with higher dosages of $\mathrm{GA}_{3}$.

Table 1. Germination percentages $(\mathrm{G} \%)$ and germination speed index (GSI) in seeds of $A$. aculeata, with or without the opercular tegument (OT).

\begin{tabular}{ccc}
\hline Seed condition & G\% & GSI \\
\hline with OT & $8.3 \mathrm{~b}$ & $0.03 \mathrm{~b}$ \\
without OT & $13.3 \mathrm{a}$ & $0.06 \mathrm{a}$
\end{tabular}

The same letters indicate an absence of significant differences in the columns according to the Tukey test at $5 \%$ probability. The means were obtained from the dosages of $\mathrm{GA}_{3}$ with or without removal of the OT. 


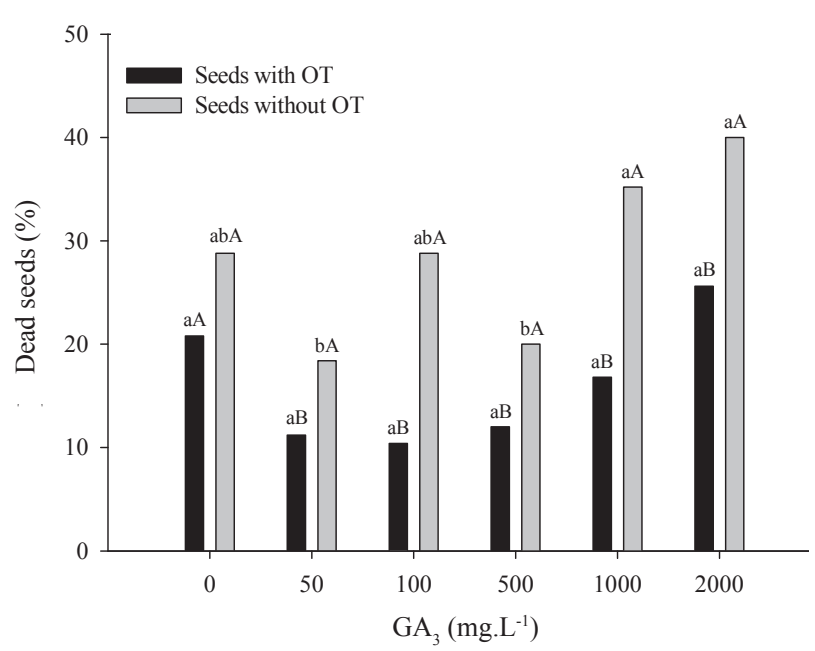

Figure 2. Mortality of A. aculeata seeds submitted or not to removal of the opercular tegument (OT) and different concentrations of $\mathrm{GA}_{3}$. The same uppercase letters indicate the absence of significant differences for the removal of the OT for each dosage. The same lowercase letters indicate the absence of significant differences between the dosages of $\mathrm{GA}_{3}$, according to the Tukey test at $5 \%$ probability.

Immersion in hydrogen cyanamide solution: the seeds used in this experiment had water content of $18.9 \%$. Removal of the opercular tegument and immersion in the cyanamide affected the germination rate and there was also an interaction between these variables. Germination did not increase with immersion in different dosages and there was no difference between the cyanamide dosages for germination but only an effect with the removal of the opercular tegument in the control (Figure 3). Repeating seed immersion in the cyanamide dosages did not stimulate seed germination.

The GSI was statistically greater in seeds with the opercular tegument removed, presenting a value of 0.05 for these seeds and 0.02 for seeds with the opercular tegument intact, but no effect was observed for immersion in hydrogen cyanamide. The effect on mortality was only seen with cyanamide immersion, there being no effect with the removal of the opercular tegument (Fig. 3). The percentage of dead seeds increased with increasing the dosages of cyanamide. The control showed a lower mortality, which differed significantly for dosages greater than $0.5 \%$.

The tetrazolium test showed a tendency for the percentage of viable embryos to decrease with increasing concentrations of cyanamide (Figure 4), demonstrating the harmful effect of this product on the embryo with increases in concentration.

The higher water uptake in the embryos compared to the other tissues were observed by McDonald Jr. et al. (1988), who noted that hydration of the embryonic axes is greater than for other structures in soybean seeds. Embryo imbibition is quick due to their chemical composition and is influenced by tissue expansion (McDonald Jr. et al., 1988; Bewley and Black, 1994).

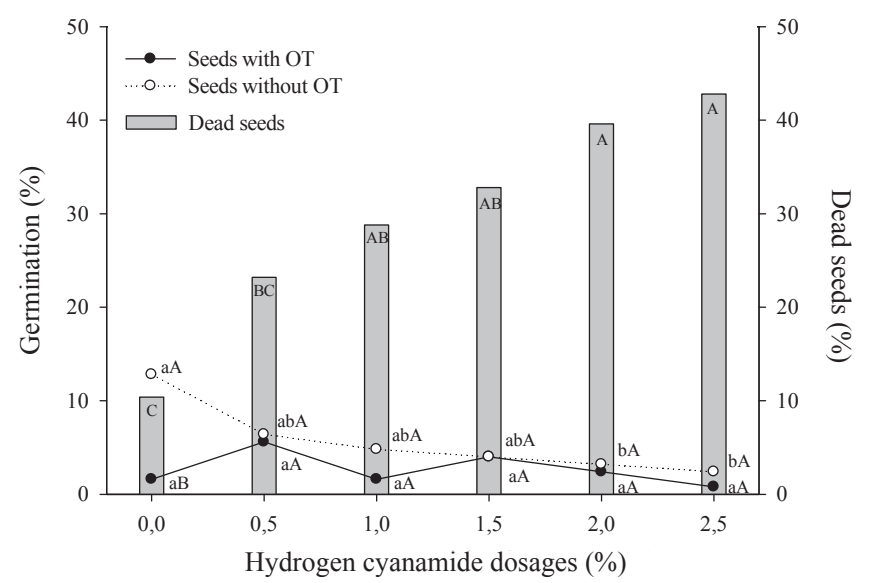

Figure 3. Germination percentages of $A$. aculeata seeds submitted or not to removal of the opercular tegument (OT), immersed in different dosages of hydrogen cyanamide and the percentage of dead seeds due to cyanamide dosages. In the rows: the same uppercase letters indicate the absence of significant differences between seed germination with or without OT for each dosage. The same lowercase letters indicate the absence of significant differences between the dosages. Histograms: the same uppercase letters indicate the absence of significant differences for seed mortality due to dosage. The means were compared by the Tukey test at the $5 \%$ probability level.

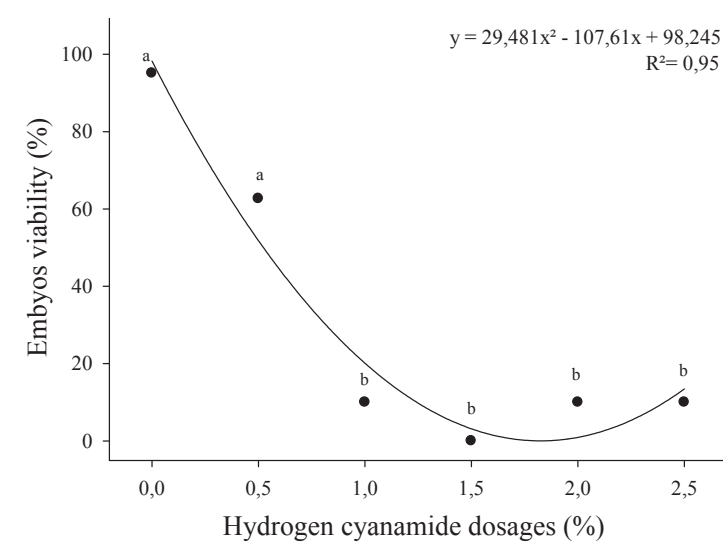

Figure 4. Percentage of viable $A$. aculeata embryos originating from hard seeds for different dosages of hydrogen cyanamide. The same letters indicate an absence of significant differences between treatments according to the Tukey test at the $5 \%$ probability level. 
The tegument is not a barrier to water uptake, which characterizes the absence of physical dormancy. The tegument of A. aculeata presents cells with thin and non-lignified walls, which do not give any mechanical resistance to the seed (Moura et al., 2010). The opercular tegument was also not a barrier to water absorption, considering that both the seeds and embryos, which did not have the opercular tegument removed, had the same final water content as those with an intact opercular tegument. However, the favorable effect on seed germination of the macaw palm was observed by Ribeiro et al., (2011), caused by removing the opercular tegument, may be related to the higher speed of water absorption by the seed embryo, where the opercular tegument was removed, as observed in the current study, as well as to a reduction in the restrictive mechanical effect (Haigh and Barlow, 1987; Welbaum and Bradford, 1990).

The efficiency of the $\mathrm{GA}_{3}$ in stimulating germination of macaw palm seeds has been described by Ribeiro et al. (2011), who observed an increase in germination with immersion in high concentrations of this growth regulator. This effect was also seen in seeds of Archontophoenix alexandrae and Ptychosperma macarthurii (Nagao et al., 1980) and Euterpe edulis (Roberto and Habermann, 2010), demonstrating that this growth regulator accelerates germination in these palms but its effectiveness is limited by its ability to penetrate in the seed tissues (Nagao et al., 1980).

Embryo viability may be compromised by prolonged immersion of the diaspores in water or solutions, with a risk of damage to cell membranes and solute leakage, together with possible restrictions in the oxygen supply (Ferreira and Borghetti, 2004; Marcos-Filho, 2005). These damages may be avoided by applying the $\mathrm{GA}_{3}$ to seeds using a culture medium (Pinheiro et al., 2001).

The low germination percentage observed in this experiment may be due to the restricted penetration of the $\mathrm{GA}_{3}$ into the seeds, since there was no direct contact of the culture medium supplemented with the $\mathrm{GA}_{3}$ with the embryos, due to the presence of micropylar endosperm, which was not removed.

The opercular tegument may limit the water and gas flows in some species and offer mechanical resistance to embryo elongation (Hussey, 1958; Al-Wasel and Warrag, 1998), which may not be observed in A. aculeata with respect to limitation of water absorption. The high percentage of dead seeds occurring with the removal of the opercular tegument may be due to a greater exposure of the embryo and to use of the MS medium, which may have served as a substrate for microorganisms. Macaw palm seeds with a high water content are more susceptible to microorganism contamination, increasing mortality rate (Rubio Neto et al., 2012), and, therefore, seed water content may have affected the percentage of dead seeds.

The use of hydrogen cyanamide to release dormancy in palm seeds has already been described by Herrera et al. (1998) and Jiménez et al. (2008), who obtained high germination percentages in Elaeis guineensis. In peach-palm (Bactris gasipaes), treatment with hydrogen cyanamide harmed germination even for short exposures times (Villalobos et al., 1992).

Hydrogen cyanamide stimulates plant tissue metabolism, increasing respiration (Goldbach et al., 1988; Or et al., 2000), and its activity in breaking seed dormancy may be due to increased lipid degradation (Amberger, 1984 apud Herrera et al., 1998). The higher mortality observed with increasing dosages of hydrogen cyanamide may be due to the long product exposure and high concentrations harming the seed (Villalobos et al., 1992; Herrera et al., 1998). The retreatment of seeds with cyanamide may have intensified these effects. The rapid metabolic activation and accumulation of peroxide caused by the product (Goldbach et al., 1988; Amberger, 1984 apud Herrera et al., 1998) may have intensified the effects of oxidation stress on the embryo, causing seed death.

Removal of the opercular tegument has also been described in other palms as a germination stimulant (Hussey, 1958; Carpenter et al., 1993; Al-Wasel and Warrag, 1998; Ribeiro et al., 2011). The removal of this layer resulted in an increase in germination speed in Rhapidophyllum hystrix (Carpenter et al., 1993) and a higher germination rate in seeds of Phoenix dactylifera (Al-Wasel and Warrag, 1998) and Elaeis guineensis (Hussey, 1958). The inefficiency of the removal of the opercular tegument, together with immersion in hydrogen cyanamide, demonstrated the harmful effect of this product in A. aculeata embryos.

\section{Conclusions}

The tegument and opercular tegument were not a barrier to water uptake by $A$. aculeata seeds, but the removal of the opercular tegument increases the speed of embryo water absorption.

The application of $\mathrm{GA}_{3}$ by culture medium on the micropylar region did not increase the germination of $A$. aculeata seeds.

Hydrogen cyanamide did not break the dormancy of $A$. aculeata seeds at the dosages tested and harmed embryo viability.

\section{Acknowledgements}

To Tatiana Arantes Afonso Vaz for help with writing this article, to FINEP for financial aid (Research Project, development and innovation in palms for the production of oil 
and the economic use of co-products and residues - Propalma) and to FAPEMIG for granting scholarships.

\section{References}

ADDAE-KAGYAH, K.A.; OSAFO, D.M.; OLYMPIO, N.S.; ATUBRA, O.K. Effect of seed storage, heat pretreatment and its duration on germination and growth of nursery stock of the idolatrica palm, Elaeis guineensis var idolatrica (Chevalier). Tropical Agriculture, v.65, n.1, p.77-83, 1988.

AL-WASEL A.S.; WARRAG, M.O.A. Effect of fruit developmental stage, seed scarification and operculum removal on seed germination of date palm. Agricola Science, v.10, p.153-161, 1998.

BASKIN, J.M.; BASKIN, C.C. A classification system for seed dormancy. Seed Science Research, v.14, p.1-16, 2004. http://journals.cambridge.org/ download.php?file $=\% 2 \mathrm{f} 30047 \_11 \mathrm{~d} 9 \mathrm{a} 98819383 \mathrm{fe} 7 \mathrm{e} 6 \mathrm{aea} 847 \mathrm{eb} 076 \mathrm{ec} 5$ journalsssrssr1401s0960258504000017a.pdf \& cover $=y \& \operatorname{code}=3 \mathrm{~d} 0 \mathrm{e} 10 \mathrm{f} 42 \mathrm{~b} 5$ $4 \mathrm{a} 09 \mathrm{e} 5 \mathrm{e} 74 \mathrm{~d} 9 \mathrm{e} 8 \mathrm{bd} 98 \mathrm{cb} 77$

BEWLEY, J.D. Seed germination and dormancy. The Plant Cell, v.9, p.1055-1066, 1997. http://www.ncbi.nlm.nih.gov/pmc/articles/pmc156979/ pdf/091055.pdf

BEWLEY, J.D.; BLACK, M. Seeds: physiology of development and germination. New York: Plenum Press, 1994. 445p.

BRASIL. Ministério da Agricultura, Pecuária e Abastecimento. Regras para análise de sementes. Ministério da Agricultura, Pecuária e Abastecimento. Secretaria de Defesa Agropecuária. Brasília, DF: MAPA/ACS, 2009. 395p. http://www.agricultura.gov.br/arq_editor/file/laborat\%c3\%b3rio/sementes/ regras $\% 20$ para $\% 20$ analise $\% 20 \mathrm{de} \% 20$ sementes.pdf

CARPENTER, W.J.; OSTMARK, E.R.; CORNELL, J.A. Embryo cap removel and high temperature exposure stimulate rapid germination of needle palm seeds. HortScience, v.28, p.904-907, 1993. http://hortsci. ashspublications.org/content/28/9/904.full.pdf + html

DIAS, L.A.S. Biofuel plant species and the contribution of genetic improvement. Crop Breeding and Applied Biotechnology, v.1, p.16-26, 2011. http://www.sbmp.org.br/cbab/siscbab/uploads/c8eb9792-df3f-def3.pdf

FERREIRA, A.G.; BORGHETTI, F. Germinação: do básico ao aplicado. São Paulo: Artmed. 2004, 323p.

FINNCH-SAVAGE, W.E.; LEUBNER-METZGER, G. Seed dormancy and the control of germination. New Phytologist, v.171, p.501-523, 2006. http:// onlinelibrary.wiley.com/doi/10.1111/j.1469-8137.2006.01787.x/pdf

GOLDBACH, H.; THALER, C.H.; WÜNSCH, A.; AMBERGER, A. Decomposition of ${ }^{14} \mathrm{C}$-labelled cyanamide in Vitis vinifera cuttings. Journal of Plant Physiology, v.133, p.299-303, 1988.

HAIGH, A.M.; BARLOW, E.W.R. Water relations of tomato seed germination. Australian Journal of Plant Physiology, v.14, p.485-492, 1987. http://www.publish.csiro.au/?act=viewfile\&fileid=pp9870485.pdf

HERRERA, J.; ALIZAGA, R.; GUEVARA, E. Use of chemical treatments to induce seed germination in oil palm Elaeis guineensis Jacq. ASD Oil Palm Papers, n.18, p.1-16, 1998. http://www.asd-cr.com/paginas/english/articulos/ bol18-1en.html

HUSSEY, G. An analysis of the factors controlling the germination of the seed of the oil palm, Elaeis guineensis (Jacq.). Annals of Botany, v.22, p.259-286, 1958.

JIMÉNEZ, V.M; GUEVARA, E.; HERRERA, J.; ALIZAGA, R.; BANGERTH,
F. Changes in hormone concentrations during dormancy release of oil palm (Elaeis guineensis) seeds. Seed Science and Technology, v.36, p.575-587, 2008.

LORENZI, H.; SOUZA, H.M.; COSTA, J.TM; CERQUEIRA, L.S.C.; FERREIRA, E. Palmeiras Brasileiras e Exóticas Cultivadas. Nova Odessa: Instituto Plantarum, 2004. 416p.

MAGUIRE, J.D. Speed of germination - aid in selection and evaluation for seedling emergence and vigor. Crop Science, v.2, p.176-177, 1962.

MARCOS-FILHO, J. Fisiologia de sementes de plantas cultivadas. Piracicaba: FEALQ, 2005, v.12, 495p.

McDONALD JR.; M.B.; VERTUCCI, C.W.; ROOS, E.E. Soybean seed imbibition: water absorption by seed parts. Crop Science, v.28, p.993-997, 1988.

MEEROW, A.W. Palm seed germination. University of Florida. Gainesville, Bulletin 274, 1991.

MOTTA, P.E.F.; CURI, N.; OLIVEIRA-FILHO, A.T.; GOMES, J.B.V. Ocorrência da macaúba em Minas Gerais: relações com atributos climáticos, pedológicos e vegetacionais. Pesquisa Agropecuária Brasileira, v.37, p.1023-1031, 2002. http://www.scielo.br/pdf/\%0d/pab/v37n7/10807.pdf

MOURA, E.F.; VENTRELLA, M.C.; MOTOIKE, S.Y. Anatomy, histochemistry and ultrastructure of seed and somatic embryo of Acrocomia aculeata (Arecaceae). Scientia Agricola, v.67, n.4, p.399-407, 2010. http:// www.scielo.br/pdf/sa/v67n4/v67n4a04.pdf

MURASHIGE, T.; SKOOG, F. A revised medium for rapid growth and bio assays with tobacco tissue cultures. Physiologia Plantarum, v.15, p.473-497, 1962. http:// onlinelibrary.wiley.com/doi/10.1111/j.1399-3054.1962.tb08052.x/pdf

NAGAO, M.A.; KANEGAWA, K.; SAKAI, W.S. Accelerating palm seed germination with gibberellic acid, scarification, and bottom heat. HortScience, v.15, p.200-201, 1980.

OR, E.; VILOZNY, I.; EYAL, Y.; OGRODOVITCH, A. The transduction of the signal for grape bud dormancy breaking induced by hydrogen cyanamide may involve the SNF-like protein kinase GDBRPK. Plant Molecular Biology, v.43, p.483-494, 2000. http://www.springerlink.com/content/ r515842463515620/fulltext.pdf

OROZCO-SEGOVIA, A; BATIS, A.I.; ROJAS-ARÉCHIGA, M; MENDOZA, A. Seed biology of palms: a review. Palms, v.47, p.79-94, 2003.

PÉREZ, H.E.; CRILEY, R.A.; BASKIN, C.C. Promoting germination in dormant seeds of Pritchardia remota (Kuntze) Beck., an endangered palm endemic to Hawaii. Natural Areas Journal, v.28, n.3, p.251-260, 2008.

PINHEIRO, C.S.R.; MEDEIROS, D.N.; MACÊDO, C.E.C.; ALLOUFA, M.A.I. Germinação in vitro de mangabeira em diferentes meios de cultura. Revista Brasileira de Fruticultura, v.23, n.2, p.413-416, 2001.

REES, A.R. Effect of high-temperature pre-treatment on the germination of oil palm seed. Nature, v.189, p.74-75, 1961.

REES, A.R. High-temperature pre-treatment and the germination of seed of the oil palm, Elaeis guineensis. Annals of Botany, v.26, p.569-581, 1962.

RIBEIRO, L.M.; OLIVEIRA, D.M.T.; GARCIA, Q.S. Structural evaluations of zygotic embryos and seedlings of the macaw palm (Acrocomia aculeata, Arecaceae) during in vitro germination. Trees, v.26, n.3, p.851-863, 2012. http://www.springerlink.com/content/fj52153874587432/fulltext.pdf

RIBEIRO, L.M.; GARCIA, Q.S.; OLIVEIRA, D.M.T.; NEVES, S.C. Critérios para o teste de tetrazólio na estimativa do potencial germinativo em macaúba. Pesquisa Agropecuária Brasileira, v.45, n.4, p.361-368, 2010. 
http://www.scielo.br/pdf/pab/v45n4/a03v45n4.pdf

RIBEIRO, L.M.; SOUZA, P.P; RODRIGUES-JUNIOR, A.G.; OLIVEIRA, T.G.S.; GARCIA, Q.S. Overcoming dormancy in macaw palm diaspores, a tropical species with potential for use as bio-fuel. Seed Science and Technology, v.39, p.303-317, 2011.

ROBERTO, G.G.; HABERMANN, G. Morphological and physiological responses of the recalcitrant Euterpe edulis seeds to light, temperature and gibberellins. Seed Science \& Technology, v.38, p.367-378, 2010.

ROBINSON, M.L. Cultivated palm seed germination. Cooperative Extension, University of Nevada. 2009.

RUBIO NETO, A.; SILVA, F.G.; SALES, J.F.; REIS, E.F.; SILVA, M.V.V.; SOUZA, A.L. Effect of drying and soaking fruits and seeds on germination of macaw palm (Acrocomia aculeata [Jacq.] Loddiges ex MART.). Acta Scientiarum Agronomy, v. 34, n. 2, p. 179-185, 2012. http://www.scielo.br/ pdf/asagr/v34n2/09.pdf
SAS INSTITUTE. SAS user's guide: statistics version. Cary: SAS Institute, 1990. 846p.

SHULMAN, Y.; NIR, G.; FANBERSTEIN, L.; LAVEE, S. The effect of cyanamide on the release from dormancy of grapevine buds. Scientia Horticulturae, v.19, p.97-104, 1983. http://ac.els-cdn. com/0304423883900493/1-s2.0-0304423883900493main.pdf?_tid=d47e1fb $83 \mathrm{a} 7 \mathrm{ff} 7121 \mathrm{~d} 0 \mathrm{fcbb} 7 \mathrm{~b} 5872 \mathrm{c} 6 \mathrm{~d} \& \mathrm{acdnat}=1337980271$ 7acee57f5c32eeef9d52 b707e21e4bd6

VILlalobos, R.; HERRERA, J.; GUEVARA, E. Germinación de la semilla de pejibaye (Bactris gasipaes). II. ruptura del reposo. Agronomía Costarricense, v.16, n.1, p.61-68, 1992. http://www.mag.go.cr/rev_agr/ v16n01_061.pdf

WELBAUM, G.E.; BRADFORD, K.J. Water relations of seed development and germination in Muskmelon (Cucumis melo L.). V. Water relations of imbibition and germination. Plant Physiology, v.92, p.1046-1052, 1990. http:/www.ncbi. nlm.nih.gov/pmc/articles/pmc1062414/pdf/plntphys00677-0190.pdf 